

Revista de la Escuela de Estudios Generales, Universidad de Costa Rica

Julio-diciembre, 2017 •Volumen 7, número 4 • EISSN 2215-3934•

Recibido: 05-Abril-2017 Aceptado: 15-Mayo-2017

\title{
El mundo de Malala: Una historia vivida en un contexto coyuntural heredero de la Guerra Fría
}

DOI: http://dx.doi.org/10.15517/h.v7i2.29594

\section{Javier Agüero García}

Universidad de Costa Rica. COSTA RICA

Correo electrónico: jav_aguero@hotmail.com

\footnotetext{
Todos los derechos reservados. Universidad de Costa Rica. Esta revista se encuentra licenciada con Creative Commons. Reconocimiento-NoComercial-SinObraDerivada 3.0 Costa Rica.

Correo electrónico: humanidades@ucr.ac.cr / Sitio web: http://revistas.ucr.ac.cr/index.php/humanidades
} 


\title{
El mundo de Malala: \\ Una historia vivida en un contexto coyuntural heredero de la Guerra Fría
}

\section{Resumen}

E Este trabajo es un ensayo interpretativo del contexto histórico en el que ha vivido Malala Yousafzai, la joven galardonada con el Premio Nobel de la Paz en 2014. Mediante la perspectiva coyuntural se parte de la invasión soviética de Afganistán, para reconocer los orígenes de un conflicto que acabó por envolver a Pakistán dentro de una realidad compleja con el establecimiento de poblaciones afganas en una región fronteriza. Acto seguido, se ahonda en el fundamentalismo pakistaní para brindar una perspectiva de un fenómeno que floreció durante el siglo XX, que empezó a tener mayor importancia en la década de 1970 y que ha sido más patente sobre todo a partir de 2001. Finalmente, se analiza la historia vivida de Malala inmersa en un entorno fundamentalista comandado predominantemente por los talibán.

Palabras claves: Historia contemporánea, Pakistán, Afganistán, guerra, Islam.

\section{Malala's World: A Vivid Story in Context Conjunctural of the Cold PostWar}

\begin{abstract}
This work is an interpretive essay on the historical context in which Malala Yousafzai, the young Nobel Peace Prize laureate, lived in 2014. Through the conjunctural perspective, one begins with the Soviet invasion of Afghanistan, to recognize the origins of a conflict Which eventually involved Pakistan in a complex reality with the establishment of Afghan populations in a border region. It then explored Pakistani fundamentalism to provide a perspective of a phenomenon that flourished during the twentieth century, which began to become more important in the 1970s and has been more evident especially since 2001. Finally, Analyzes the lived history of Malala immersed in a fundamentalist environment commanded predominantly by the the Taliban.
\end{abstract}

Keywords: Contemporary history, Pakistan, Afghanistan, war, Islam. 


\section{Introducción}

¿Cuál es el contexto coyuntural que rodea la historia vivida de Malala como habitante de Pakistán? ¿Qué efectos tuvo la invasión soviética de Afganistán en la historia de Pakistán? ¿Cómo ha incidido el desarrollo del fundamentalismo islámico en la historia pakistaní? ¿Cómo se inserta la historia vivida de Malala dentro de un Pakistán convulso?

Estas interrogantes surgen a raíz del interés de estudiar la figura de Malala Yousafzai, la joven galardonada con el Premio Nobel de la Paz. Su historia forma parte del entramado sociopolítico del torbellino que ha azotado a Pakistán, el país que vio nacer a esta mujer aclamada mundialmente.

Según Malala, su entorno de vida durante la niñez fue tranquilo y apacible,

"Pero las cosas cambiaron. Cuando tenía diez años, Swat, que era un precioso lugar turístico, se convirtió de repente en un nido de terrorismo. Más de 400 escuelas fueron destruidas. Se prohibió que las niñas fueran a la escuela. Las mujeres recibían palizas. Se mataba a personas inocentes. Todos sufríamos. $Y$ nuestros sueños maravillosos se convirtieron en pesadillas". (Yousafzai, 2014ª, p. 2).

Las palabras anteriores fueron pronunciadas por la joven Malala cuando contaba con diecisiete años de edad con ocasión de la recepción del Premio Nobel de la Paz en diciembre de 2014. Se trataba de una joven de nacionalidad pakistaní, acostumbrada a esconder sus cuadernos bajo su velo para asistir clandestinamente al centro de estudios. Esta muchacha decidió levantar su voz en contra de quienes violentaban su derecho como mujer a la educación de su país. Luego de recibir distintas condecoraciones, Malala fue galardonada con la máxima distinción otorgada por el Comité Nobel Noruego; en conjunto con el indio Kailash Satyarthi, convirtiéndose en la persona de menor edad en recibir tal distinción.

¿Pero quién es Malala en realidad? Para empezar, la respuesta puede responderse haciendo eco de las palabras del filósofo Ortega y Gasset cuando aseveraba con justificada razón que "yo soy yo y mis circunstancias". El ser humano es un ente eminentemente social y debe estudiarse en medio del entorno en que se desenvuelve, a partir de allí, se puede comprender su naturaleza en toda su dimensión contextual. En este sentido el abordaje, por medio del prisma de la historia, sugiere ser de utilidad porque se esmera, por sobre todo, en establecer el hilo conductor entre el presente con el pasado. La historia es una disciplina encargada de aportar interpretaciones contextuales necesarias para ubicar en su dimensión más amplia a los actores sociales, como es el caso de Malala, portavoz de reivindicaciones de derechos muchas veces pisoteados en su país.

En el plano temporal, dentro del tipo de duraciones del tiempo histórico, se distingue la coyuntura. De acuerdo con Braudel (1989) es la mediana duración; el tiempo de las crisis económicas, políticas y sociales. La coyuntura se ubica en un nivel intermedio y por tanto, ofrece la oportunidad al estudioso de la historia de brindar explicaciones que trascienden el episodio fugaz y que además, no pretende el abordaje del tiempo de las estructuras en donde imperan las continuidades.

Así entonces es atinente ubicar a la Premio Nobel como testigo de una sociedad musulmana en Pakistán. Malala experimenta una historia vivida, definida ésta -según Heller (1999)- como una 
dimensión ontológica-existencial de la persona que comparte con la comunidad. Para esta autora de origen húngaro: "la historia vivida es rememorada junto con los demás porque conforma una experiencia compartida y en el caso específico de una experiencia dolorosa, ésta no se olvida porque se integra a la vida misma” (Heller, 1999, p. 67-70).

La historia vivida de Malala es conocida a través de testimonios en dos textos: Yo soy Malala (2013) y Malala mi historia (2014). Su mensaje parte de su condición de habitante de una región en donde la guerra, la opresión y la violencia forjaron el carácter de una mujer en favor de la no discriminación.

En medio de estas acotaciones de análisis aportadas por la historia, se teje el desarrollo de este escrito que consiste, en primer lugar, en brindar una caracterización de una coyuntura histórica específica heredera de condiciones remontadas a tiempos pretéritos que datan, principalmente, de la invasión soviética a Afganistán, país vecino de Pakistán. Ambos países de Asia Meridional, a su vez, forman parte de un complejo regional más amplio típico de una encrucijada del planeta conformante de lo concebido a principios del siglo XX por el geógrafo Mackinder (2010) como "el pivote geográfico de la historia".

En segundo lugar, se trata de puntualizar las generalidades del fundamentalismo musulmán abocado a una práctica de los preceptos del Islam de acuerdo con sus enseñanzas primigenias, según la lectura literal del texto revelado al profeta. En tercer lugar, se analiza a Malala como una figura en el centro de la historia vivida en medio de un país convulso caracterizado por la agudización de las tensiones regionales propias de la última fase del mundo bipolar y de la posguerra fría.

El propósito radica en ubicar a Malala en el plano histórico de la coyuntura para aprehender la trascendencia de los hechos que han fraguado una historia de vida merecedora de tantos galardones a nivel internacional. Para cumplir con el cometido de brindar una respuesta se estudiarán los aspectos siguientes.

-La invasión de Afganistán por parte de la Unión Soviética, constituyó un conflicto clásico de la Guerra Fría durante su última fase. Sus efectos se hicieron sentir en el país vecino de Pakistán, al punto que la situación contemporánea de este último país resulta imposible de entender sin conocer lo acaecido desde fines de la década de 1970, cuando la fase de la distensión llegaba a su ocaso.

-La génesis y posterior evolución del fundamentalismo islámico en razón de que estas posiciones obedientes a concepciones asociadas al extremismo islámico, han sido clave en los procesos más recientes responsables de dar un golpe de timón a la historia reciente de territorios otrora de interés de las potencias hegemónicas durante la época de la Guerra Fría.

-La historia vivida de Malala como protagonista, en medio de un proceso de radicalización de las posiciones del movimiento talibán, se asume aquí como un testimonio de una persona esforzada por luchar por el derecho de la educación. Alrededor de su constante denuncia, se teje una vida plagada de limitaciones de una población que, paulatinamente observa los efectos del control de su cotidianidad por parte de posiciones fundamentalistas.

En el plano del contenido, es menester aclarar que este ensayo no se esmera en analizar los textos de Malala desde la óptica literaria. Tampoco se pretende adentrar en la discusión acerca de las supuestas filiaciones ideológicas de Malala en lo concerniente a su relación con los poderes occidentales. Primero, porque la elección del objeto de estudio incluye exclusivamente la caracterización del 
contexto de Pakistán y de su vecino inmediato, Afganistán. Segundo, porque de haberle asignado el tratamiento si la Premio Nobel obedece, o no, a intereses allende al país que la vio nacer, amerita elaborar otro trabajo aparte.

\section{La invasión soviética a Afganistán}

Dieciocho años antes del nacimiento de Malala, la Unión Soviética dirigida por Leonidas Brezhnev - una figura que se acercaba al crepúsculo de su gobierno- en unión de sus colaboradores más cercanos, dieron el banderazo de salida para que se invadiera un país limítrofe al sur de su imponente territorio. Afganistán constituía una parte de la Casa del Islam (Dar-al-islam), una tierra que históricamente era el punto de confluencia de las rutas comerciales desde la antigüedad, como la de la seda, y que además, nunca había podido ser doblegada por ningún poder extranjero. Eran territorios abiertos a los jinetes nómadas; que al igual que Pakistán, forman parte de una región más amplia clave por su geoestraticidad, fronteriza con grandes poderes, descrita por Mackindler (2010) como el corazón de Eurasia. El objetivo de Moscú era evitar una eventual instalación de misiles estadounidenses en Afganistán y además colocar un gobierno capaz de dotar de estabilidad a ese país. El líder del partido comunista afgano se encontraba amenazado por fuerzas adversarias de tipo fundamentalista deseosas de hacerse con el poder. Para Burbank y Cooper (2012):

"Los líderes soviéticos seguían pensando que tenían una misión civilizadora que cumplir en Asia Central. En 1979 el Ejército Rojo entró en Afganistán -país que los constructores de imperios habían intentado someter una y otra vez en el pasado-, con la intención de respaldar a un régimen cliente". (p. 586).

Como lo considera White (2015), tiempo atrás durante los primeros años de la Guerra Fría, Afganistán era un Estado de tipo rural, con unos quince millones de habitantes con predominancia sunní (84 \%), cliente de Moscú y cultivador de buenas relaciones de buena vecindad con esta potencia; Nikita Jrushev lo había visitado en la década de 1950. Los soviéticos surtían de armamentos a la monarquía gobernante en Kabul, ciudad capital de Afganistán. En 1973, el rey Mohammed Zahir, perteneciente a una estirpe gobernante desde más de dos centurias, estaba deseoso de modernizar el país mediante la transición hacia una monarquía constitucional. Mientras disfrutaba de sus vacaciones en Europa ocurrió un golpe de Estado por parte de su primer ministro, un príncipe educado en Francia, Mahamed Daoud Khan. Este nuevo dignatario acariciaba la idea de apoderarse de los territorios pashtunes pakistaníes y de implementar un proyecto modernizador en un país de base agrícola, de la mano con el Partido Democrático del Pueblo Afgano autoproclamado como comunista.

Daoud ansiaba acercarse a los Estados Unidos, congraciándose con el Sha de Irán quien era incondicional con Washington, con la finalidad de obtener ayuda militar de la potencia occidental para así disponer del músculo político necesario para reclamarle a Pakistán territorios irredentos habitados por pashtunes. Estas tierras se encontraban agrupadas en la FATA (Áreas tribales de Administración Federal de Pakistán), los pashtunes son tribus de tradición nómada de una lengua irania oriental, con una amplia trayectoria de lucha en contra del dominio persa y mongol y se ubican entre Pakistán y Afganistán. Luego del intento fallido de crear un territorio autónomo, fueron separados por la línea de la frontera cuando se crearon dichos Estados; su número asciende a los cuarenta millones. 
El esfuerzo de modernización del nuevo dignatario Daoud le costó la vida y fue asesinado en abril de 1978. Mientras tanto, se consolidaba en la Universidad de Kabul el Jami`at-e Islami, un grupo de islamista inspirado en la Hermandad Musulmana, que empezó a operar en la clandestinidad; más tarde buscarán refugio en la ciudad capital fronteriza de Peshawar en el noroeste de Pakistán. La agrupación era dirigida por el erudito docente de filosofía, Burhanuddin Rabbani, quien a su vez se apoyaba en el comandante tayiko Ahmed Sha Massud. Peshawar fue testigo del surgimiento de la primera generación urbanizada y alfabetizada masivamente; esta labor corrió por cuenta del partido islámico de Gulbudin Hekmatyar, el Hezb-e Islami, que enrolaba en sus filas a pashtunes, predominantemente. Este grupo tenía gran afinidad con los Hermanos Musulmanes, el movimiento wahabista saudí y la Jama' et-e Islami pakistaní. Tanto Rabbani como Hekmatyar se perfilaban como mujahidines, "los soldados de Dios" o señores de la guerra; ambos líderes ansiaban el cambio. El último de ellos apostaba por la vía revolucionaria, y al mismo tiempo, fue el precursor de financiar la guerrilla por medio de los jugosos recursos deparados de la producción y del tráfico de estupefacientes, junto con el trasiego de armas (Esparza, 2015).

El nuevo líder afgano al frente del poder posterior al golpe de 1978 fue Nur Mohamed Taraki quien, luego de expropiar las empresas de Rabbani, dio inicio a una serie de reformas que, pese a su naturaleza de combatir el alto desempleo en un país rural, exacerbó aún más los ánimos entre comunistas y tradicionalistas. Así brotaron revueltas islámicas bajo el apoyo de Irán, que denunciaban los abusos de los gobiernos de Zahir y de Daoud, anteriores figuras políticas dirigentes de Afganistán. Los cabecillas de esas revueltas fueron derrotados y huyeron a Irán. Lo sucedido mantenía a los soviéticos en vilo ante lo que podía suceder en ese país limítrofe.

Para complicar aún más este escenario, la Revolución Islámica de contenido shií, que acabó con deponer el gobierno de la dinastía Pahlavi en Irán, ocurrida entre enero y abril de 1979, se constituyó en un factor de que puso a pensar al gobierno de Moscú, pues se temía el eventual derrumbe del régimen afgano, como resultado de un efecto dominó a partir de la caída del Sha, que tendría implicaciones a mediano plazo en una amenaza para la estabilidad de las repúblicas soviéticas de Asia Central: Turkmenistán, Uzbekistán, Kazajistán, Kirguistán y Tayikistán.

Parafraseando a Judt (2012) estos territorios musulmanes contaban con una nueva generación musulmana tentada de soñar con la emancipación política de Moscú. Ante este panorama tan adverso las autoridades soviéticas optaron por incrementar la colaboración a Mohamed Taraki.

Mientras se destronaba al Sha de Irán en marzo de 1979, tanques locales y aviones soviéticos arrasaron con la ciudad afgana de Herat al oeste del país. La justificación fue aplacar una sublevación de trabajadores descontentos con los proyectos de laicización llevados a cabo por parte del gobierno comunista. Las víctimas se contabilizaron en 20 000. La escalada de violencia iba en ascenso y en setiembre del mismo año, en una reunión con Brezhnev, Taraki le solicitó al líder soviético el envío de refuerzos para controlar la situación de su país, y de paso, poner coto a los excesos en el ejercicio del poder por parte de su primer ministro, Hafizullah Amin.

Sin embargo, de momento no se tomó en cuenta su petición en razón del riesgo del aumento del grado de convulsión en Afganistán. Pero esta determinación soviética sufrió un giro vertiginoso en cuanto el Kremlin se enteró del asesinato de Taraki pocos días después de su retorno a Kabul, luego de aquella reunión con el máximo dignatario de la URSS. Quien asumió el poder fue Amin, otro comunista educado en los Estados Unidos. Amin se había reunido con Adolph Dubs, el embajador estadounidense para establecer contactos entre islamistas, la Agencia Central de Inteligencia (CIA) y 
los servicios secretos de Pakistán (ISI). Este último ente tenía amplia experiencia en la organización de las guerras contra la India por la disputa de Cachemira y en el desarrollo de programas nucleares. Para sorpresa de muchos, el embajador de la potencia norteamericana fue secuestrado y asesinado en Afganistán durante los primeros meses de 1979.

Los entendimientos en mención sellaron la alianza de la Casa Blanca con los grupos anticomunistas locales. En esos encuentros se alentaba a los islamistas en contra del gobierno afgano de orientación laica, esta opción era apoyada por Walter Slocumbe, el secretario de defensa estadounidense y por Zbigniew Brzezinski, el consejero de seguridad nacional del presidente Jimmy Carter, quien temía la avanzada del control soviético y la virtual amenaza al acceso del petróleo del Golfo Árabe-Pérsico. A su vez, este constituyó uno de los pilares de la doctrina Carter, expuesta en enero de 1980 con ocasión de una arenga sobre el Estado de la Unión.

Con este deseo, el presidente estadounidense emitió una autorización presidencial a la CIA a fin de apoyar a los mujahidin afganos (grupos islamistas rebeldes), organizó una coalición integrada por Pakistán, China, Arabia Saudí, Egipto y Gran Bretaña en contra de la presencia soviética en Afganistán. Con estas acciones se daba garantía a Pakistán de protección ante cualquier agresión procedente de la URSS. Según Fontana (2011), la conjunción de estos factores inducidos por los Estados Unidos dio origen al "santuario de las guerrillas".

Esta posición tomó mayor relevancia a partir de la desaparición del Sha de Irán con el derrumbe de su régimen dinástico. El anticomunista Brzezinski se dio a la tarea de localizar a los mujahidines exhortándoles a iniciar una Guerra Santa (yihad) antisoviética, con carácter preventivo para así evitar que Afganistán sirviera de foco comunista y, de paso con esta acción, se pudiera alentar movimientos subversivos al resto de Asia Central conducentes a la desestabilización del área que concentraba a cinco republicas conformantes de la Unión Soviética.

Como se verá más tarde, estas Guerras Santas, catalogadas por Cooley (2002) como "guerras profanas" reclutaron a miles de mercenarios islámicos de todo el mundo, convertidas luego en una importante fuerza de ataque. Por su parte, paradójicamente, Carter autorizó subrepticiamente a la CIA a realizar operaciones en Afganistán a pocas semanas después de celebrado un acuerdo con Brezhnev acerca del desarme. Como lo indica Fontana (2011), estas acciones encubiertas de la CIA se dieron a unos seis meses antes de la invasión soviética a Afganistán.

En un segundo momento, una vez traspasada la frontera afgana por parte de sus tropas, Carter enfurecido informó por el teléfono rojo a Brezhnev que la invasión constituía una amenaza para la paz, por eso decidió interrumpir los envíos de cereal con destino a la URSS y además boicoteo los Juegos Olímpicos a realizarse en Moscú en 1980. Así se concluyó la fase de la distensión y se inició un renacimiento de la Guerra Fría (McMahon, 2009).

Lo agreste de la geografía montañosa del Hindu Kush, no fue óbice para que al final, el 24 de diciembre, la URSS decidiera atravesar el río Amu Daria, pasando primero por el Kurdistán soviético para así llegar a Afganistán. La guerra propiamente dicha en Afganistán sobrevino inmediatamente después de la invasión de las tropas soviéticas el 27 de diciembre de 1979, el mismo día del asesinato del primer ministro Amin por parte de la KGB.

Esto sucedió luego del otoño, cuando se registró la crisis de los rehenes estadounidenses en Teherán, la capital de Irán, quienes fueron retenidos por el Gobierno recién victorioso encabezado por el 
Allatolah Ruhollah Jomeini. Con la invasión a Afganistán se proclamó a Babrak Karmal, un primer ministro impopular ante los ojos de los islámicos, que dio inicio a una política de reformas sociales portadoras de un programa de tolerancia y de educación hacia las mujeres.

Conforme se echaron a andar las reformas propuestas por el gobierno de orientación comunista brotaron los enfrentamientos con los grupos islámicos, quienes simultáneamente se habían empezado a organizar en una guerra de guerrillas; aspecto particular latente durante todo el conflicto. En términos geopolíticos y de las relaciones internaciones, "La ocupación rusa de Afganistán en 1979 provocó temores, justificados o no, ante la posibilidad de que la Unión Soviética pudiera proponerse ampliar aún más el control en la región del océano Índico" Hourani, 2008, pp. 503-504).

La guerra en sí, iniciada con la invasión soviética, fue tácticamente un enfrentamiento centrado, más que nada, en pequeñas ofensivas locales contra un conjunto de señores de la guerra y de rebeldes y el armamento pesado era poco útil debido a lo escarpado del territorio afgano. De los casi 100000 soldados que tenía la URSS en Afganistán para 1984, si acaso estaba disponible el $10 \%$ para el combate ofensivo (White, 2015).

Para los observadores de la época, fue una guerra, que desde el principio se sabía que estaba perdida para los soviéticos; pero al país invasor le demoró diez años para llegar a comprenderlo, cuando tuvo que retirarse hacia las fronteras septentrionales con rumbo a su país. Durante este enfrentamiento los mujahidines empezaron a controlar prioritariamente los espacios rurales de más difícil acceso, desde donde realizaban la guerra de guerrillas islámicas; para ello dependían de la seguridad brindada por Irán y Pakistán, allí las tropas se capacitaban y se recuperaban. Además, los Estados Unidos les ofrecían ayuda, merced al apoyo incondicional de Arabia Saudita gobernada por una monarquía conservadora afín a Washington, toda esta colaboración se canalizaba por medio de Pakistán; país vecino interesado en controlar Afganistán a través del establecimiento de un Estado Islámico fiel a los designios anticomunistas de Islamabad y de Riad.

Por otra parte, la Unión Soviética durante la segunda mitad de la década de 1980, una vez muerto Brezhnev bajo la dirección de Mijail Gorbachov, emprendió una serie de reformas, contenidas en la Perestroika y en la Glasnost, que replantearían indirectamente el papel de la guerra en Afganistán, quedando reducido el papel soviético a las actividades meramente defensivas.

En 1986 el presidente Karmal cayó en desgracia y se retiró a Moscú y asumió el poder Mohamed Najibullah. Este último asistió a un desgaste progresivo de las condiciones sociopolíticas afganas caracterizadas por el creciente apoyo de la Casa Blanca a los grupos extremistas islámicos; en 1992 cayó el Gobierno comunista de Najibullah en manos de los mujahidín, cuando ya no se contaba con el apuntalamiento soviético. Fue sustituido por Rabbani. Más tarde, Najibullah fue ejecutado por los talibán en 1996, luego de la toma de Kabul.

Para la segunda mitad de 1987, la guerra ya iba en caída libre; se firmaron los acuerdos de Ginebra que normalizaban las relaciones entre Afganistán y Pakistán. Sin embargo, dicha negociación excluyó a los mujahidines y esto se convirtió en el inicio de otro conflicto local mientras tanto la guerra no acababa y se ponía de manifiesto que la paz no era posible.

En términos políticos la guerra de Afganistán fue el último conflicto típico de la Guerra Fría con lo que se puso punto final a la "pax soviética". Para Segura (2001): 
"Sin la intervención soviética y la particular coyuntura de la década de los ochenta, Afganistán no habría sido más que uno de los múltiples conflictos nacionales o regionales que se dieron durante la Guerra Fría y la segunda mitad del siglo XX” (p. 200).

En febrero de 1989, después de aproximadamente diez años de combate infructuoso, la Unión Soviética bajo las riendas de Mijail Gorbachov decidió emprender la retirada de Afganistán en virtud de reconocer esa guerra como "una herida sangrante". La derrota fue rotunda y el trauma fue similar al de Vietnam para los Estados Unidos: los veteranos que regresaban a su país revelaron la magnitud del desastre de Afganistán; ofreciendo así una perspectiva diferente a la opinión prevaleciente en el público promedio, desinformado por parte de los medios de comunicación oficiales. Se había hecho una idea complemente falsa de lo sucedido en ese país musulmán asiático.

En el plano económico tuvo un costo semejante al de la Guerra del Golfo de 1991, provocada por la invasión de Irak en agosto de 1990 que inmediatamente generó una escalada en las tensiones, desembocando luego en la Operación Tormenta del Desierto. Pero mientras los Estados Unidos salió victorioso luego de derrotar al dictador iraquí, Saddam Hussein; la URSS salió agotada y en bancarrota (White, 2015); la guerra de Afganistán fue el Vietnam estadounidense y también constituyó uno de los factores que incidió en su disolución en 1991.

Las implicaciones de la pesadilla afgana han sido tema de discusión aún hoy, a más de un cuarto de siglo, del abandono del campo de batalla; se sopesa el grado de influencia que tuvo esta desventura militar en la posterior desintegración de la Unión Soviética. Para Judt:

"En pocas palabras, Afganistán fue una catástrofe para la Unión Soviética. Sus traumáticas consecuencias para toda una generación de soldados de reemplazo no surgirán hasta pasado un tiempo. A comienzos de la década de 1990 se calculaba que uno de cada cinco veteranos de guerras afganas era un alcohólico empedernido; en la Rusia postsoviética muchos otros, [eran] incapaces de encontrar un empleo estable" (p. 855).

Los resultados de esta guerra, denominada por Fontana (2011) como "la trampa afgana", fueron aún peores en el propio suelo donde se libraron las diferentes batallas; porque resultaría muy aventurado aseverar que Afganistán salió victorioso luego del trago amargo de la derrota soviética; fue la única en su especie durante la Guerra Fría por ser directa; la URSS nunca había invadido un país fuera de las fronteras del Pacto de Varsovia.

Afganistán se constituyó: "en un ejemplo paradigmático de estado fallido" (Sánchez, Mañé, de la Cámara y Huici, 2013) y además se convirtió en el país "más catastrófico del mundo", en palabras de Rashid (2001). Con una experiencia aciaga, Afganistán llegó a contabilizar un millón de muertos; además quedó destruido, reducido a escombros, y la sequía que lo azotó en 1990, acentuó la devastación aunada a la guerra civil, surgida luego de la salida de los soviéticos, que configuraría en esos mismos años, el rostro actual del país: “un esqueleto descarnado de un Estado” (Edwards, 2002, p. 110).

Los indicadores actuales de Afganistán siguen siendo desalentadores: un déficit neto de producción de alimentos, un altísimo nivel de pobreza, un consumo excesivo de drogas, un desempleo crónico, una esperanza de vida que a duras penas supera los cuarenta años y con una tercera parte de su población en condición de migrantes y de refugiados que huyeron de su país de origen hacia Irán y Pakistán, principalmente (Tabla 1). 


\title{
Tabla 1
}

\section{Cantidad de refugiados afganos por países}

(1979-1989)

\begin{tabular}{|r|r|r|r|r|}
\hline Año & \multicolumn{1}{|c|}{ Pakistán } & \multicolumn{2}{|c|}{ Irán } & Total \\
\hline $\mathbf{1 9 7 9}$ & 402000 & 100000 & & 502000 \\
\hline $\mathbf{1 9 8 1}$ & 2375000 & 1500000 & 2700 & 3877700 \\
\hline $\mathbf{1 9 8 3}$ & 2873000 & 1700000 & 5300 & 4578300 \\
\hline $\mathbf{1 9 8 5}$ & 2500000 & 1800000 & 5900 & 4305900 \\
\hline $\mathbf{1 9 8 7}$ & 3156000 & 2350000 & 5200 & 5511200 \\
\hline $\mathbf{1 9 8 9}$ & 3272000 & 2350000 & 8500 & 5630500 \\
\hline
\end{tabular}

Fuente: Elaboración propia a partir de Baltar, E. (2014)

Aunado a esta situación migratoria tan compleja existen características que convierten a Afganistán en el quinto país más pobre del planeta. Al respecto resulta revelador el testimonio de una familia afgana desplazada residente en un campo de refugiados en Nasir Bagh: regresó a su país, habita en las montañas de Tora Bora y su drama por sobrevivir es más que patético porque

\begin{abstract}
"Ante la falta de empleos en Afganistán, el esposo vive en Peshawar, donde trabaja en una panadería. El dólar que gana al día se desvanece como el humo por las dolencias de ella [su esposa Sharbat]; el asma que padece le impide tolerar el calor y la polución de Peshawar y la obliga a estar con él sólo en invierno; por ello, el resto del año Sharbat vive en las montañas" (Newman, 2002, p. 7).
\end{abstract}

De acuerdo con el fragmento anterior, el problema de los refugiados es un corolario de la invasión soviética a Afganistán, pues lejos de lograr su objetivo, la política de Moscú provocó un viaje sin derecho a retorno en medio de la violencia; consistió en una gran oleada de desplazados que convirtieron esta situación en un asunto mundial sin parangón alguno (Baltar, 2014).

Evidentemente, el fenómeno más importante que marcó la historia de Afganistán a partir de la salida de los soviéticos, fue la instauración de un régimen político en manos de los talibán, con prioridad de conquista de las provincias productoras de amapola, materia prima para la obtención de opio, de Helmand y Lashargargh. Los talibán eran integrados por anticomunistas predominantemente de origen pashtun afgano y pakistaní; en su mayoría avituallados y financiados por los Estados Unidos, vía Pakistán, durante la guerra contra el poder de Moscú.

Los talibán, formalmente fundados en 1994 por el mullah (sacerdote extremista) Muhammad Omar, eran constituidos por estudiantes conservadores procedentes de las escuelas islámicas y los antiguos mujahidín (los rebeldes islámicos). En palabras de Cooley (2002), los talibán son "el monstruo del extremismo islamista". En el criterio del mismo autor, basado en una apreciación de Winston 
Churchill, las tribus pashtunes históricamente habían estado relacionadas con guerras públicas y privadas. Los talibán se originaron en ese espacio y han sido los protagonistas de las promesas portadoras de paz a una población exhausta por el imparto de los conflictos armados.

La aparición de los talibán, ha unido los destinos de Pakistán y de Afganistán en una sola realidad de sectores islámicos extremistas que claman por volver a las raíces del Islam según la lectura literal del Corán; esta es una de las características del fundamentalismo islámico, el tema a desarrollar a continuación.

\section{Hacia una caracterización del fundamentalismo en Pakistán}

En setiembre de 1987, con ocasión de una reunión con la presencia del ministro de Asuntos Exteriores de la Unión Soviética, Eduard Shevarnadze, y del Secretario de Estado de los Estados Unidos, George Schultz, se dio una advertencia muy particular acerca de la génesis de un peligro que acecharía a esta región en el futuro. Al inicio el personero estadounidense intentó llamar la atención de Shevarnadze al persuadirle y recomendarle adoptar un nuevo enfoque en el caso de Afganistán en momentos en que el conflicto aún estaba lejos de concluir.

Para el soviético, en cambio, era necesario que Schultz entendiera, de una vez por todas, la condición especial del ascenso del fundamentalismo islámico en virtud del inminente potencial de llegar a convertirse en un peligro de mayor envergadura para Occidente que el mismo comunismo. Como era de esperarse en el marco de la Guerra Fría, no se registró ningún tipo de acuerdo al respecto; por tanto, no hubo humo blanco para lograr un eventual entendimiento entre las dos partes (White, 2015).

La advertencia de Shevarnadze ante la amenaza latente en un estado de incubación de una futura revancha por parte del Islam en la figura del fundamentalismo se comprende mejor hoy, tres decenios después. Pero ¿qué es el fundamentalismo? Como punto de anclaje histórico es menester señalar que el Islam es la única de las grandes religiones que ha experimentado un crecimiento porcentual en cuanto al número de creyentes a lo largo del siglo XX.

Situación contrastante con la religión tradicional china que ha presenciado una disminución de un 23,46\% en 1900 a un 6,30 \% en 2010, atribuida principalmente al movimiento de la Revolución Cultural impulsado por Mao Zedong. El budismo y el hinduismo han mantenido, con algunas variaciones, el porcentaje del número de creyentes; mientras que el cristianismo ha visto reducido su cantidad de seguidores (Núnez, 2015). Esa consideración hace del Islam una religión particular dado que ha aumentado su cobertura en medio de un contexto mundial cada vez más secularizado abanderado de la separación entre las esferas del Estado y el mundo de la espiritualidad.

El fundamentalismo islámico ha florecido durante el siglo XX dentro de un contexto muy particular que se remonta a los tiempos del final de la Primera Guerra Mundial cuando, en medio de la caída de los imperios, se disolvió el Imperio Otomano; la unidad política aglutinante de territorios extendida desde el norte de África hasta parte de la Meseta Irania. La muerte del citado poder imperial dejó la puerta abierta para que las potencias occidentales, sedientas de apoderarse de territorios, irrumpieran en el reparto de estas tierras mediante la figura de mandatos creada por el presidente Woodrow Wilson durante las postrimerías de la Gran Guerra. 
Casi podría aseverarse, como lo señala Pagden (2011), que todo el botín otomano fue repartido por Occidente a excepción de Turquía, el Estado recién nacido bajo un formato secular y occidental fruto de la acción independentista de índole nacionalista y decidida de Mustafa Kemal (Atatürk). Turquía se convirtió en un Estado laico, obligó al uso de un apellido, adoptó el atuendo europeo, cambió su forma de escritura por el alfabeto latino (sustituyendo al árabe utilizado desde centurias atrás); y además, el sistema jurídico tradicional fue reemplazado por uno nuevo basado en el derecho italiano; de la misma forma, la codificación tiene inspiración suiza y alemana.

En términos retrospectivos, el fundamentalismo es un proceso de larga duración, se puede señalar, según lo indica Kienzler (2011), que hunde sus raíces en los siglos X y XII cuando el islamismo se afianzó como sistema político y religioso bajo las premisas siguientes: 1) Dios como origen único de lo existente; 2) el creyente musulmán consciente de esta situación debe vivir con sentido pleno de la salvación; y 3) el orden perfecto a seguir es el dispuesto por la comunidad islámica instaurada por Mahoma en la ciudad de Medina. A inicios del siglo XI, se registró una crisis política derivada del derrumbe del califato y de ahí surgió el pensamiento sunní de Ibn Habib al-Mawardi propulsor de instaurar un orden universal islámico. En sí el fundamentalismo procura el establecimiento de un equilibrio basado la sujeción a la ley emanada por la comunidad islámica y en el rechazo de lo novedoso.

Luego durante el siglo XVIII, se registró otro hito coadyuvante en la configuración del fundamentalismo cuando se formuló el movimiento wahabí entre la comunidad sunní; propugnaba la puesta en práctica de la ley islámica (sharia) tanto en lo referente a la norma como en el afán expansionista. Esta corriente fue adoptada por la dinastía gobernante en Arabia, que con el tiempo, se vio beneficiada con las jugosas ganancias deparadas de la explotación de los yacimientos petroleros a partir de la década de 1930. El wahabismo disponía de cuantiosos recursos económicos y se hizo con el control de la Meca, la ciudad santa del Islam (Núñez, 2015).

Más recientemente, el punto de arranque del fundamentalismo contemporáneo se puede ubicar en 1928 con la fundación en Egipto de los Hermanos Musulmanes bajo el liderazgo del profesor de la Ismailía, Hasan al Banna (1906-1948), quien consideraba el islamismo como "un orden global que abarca todos los aspectos de la vida: Estado, patria, gobierno, moral, ciencia y derecho, bienes materiales, riquezas y bienestar, compromiso y oración, doctrina y veneración" (Kienzler, 2011, p.104). El fundador de los Hermanos Musulmanes, a su vez, se nutrió de las ideas del pensador Jamal al-Din al-Afghani quien formuló tesis de tipo reformista durante el siglo XIX. Para al-Afghani era necesaria la instauración de un Estado Islámico.

Para Armstrong (2013), el fundador del fundamentalismo islámico en su versión sunní fue Sayib Qutb, quien a su vez recibió la influencia del pakistaní Mawdudi y se sumó a movimiento de los Hermanos Musulmanes. Fue un duro crítico del laicismo practicado por Gamal Abdel Nasser en Egipto; dentro de su proyecto figuraba el establecimiento de un Estado musulmán auténtico. Los talibanes, gobernantes de gran parte de Afganistán desde 1994, bebieron de la ideología de Qutb; de ahí que defiendan a ultranza el papel de los ulemas como dirigentes de la cosa pública y el uso del velo en las mujeres. De esta manera,

"Su programa incluía también implantar la sharia y un Estado teocrático donde el mulá designaría y controlaría el gobierno, prohibiendo las elecciones y los partidos políticos. Su visión de la sharia era muy conservadora y deudora del estricto código pastún tradicional. Prohibieron cualquier actividad pública de las mujeres, la música y la representación de 
seres vivos, y la homosexualidad masculina y el adulterio eran castigados con la lapidación pública. La dictadura teocrática de los talibanes conculcaba los derechos humanos fundamentales y practicaba una exclusión de género sin precedentes. Además, la miseria y la pobreza hacían todavía más brutal, rígido e insoportable del fundamentalismo talibán" (Segura, 2013, p. 168).

Debe hacerse hincapié, como bien lo indica Kepel (2005), que la década de 1970 se constituyó en una coyuntura "bisagra" entre las relaciones entre religión y política, que contrario al proyecto ilustrado en aras del progreso, representó en el cristianismo y en el Islam, una nueva época de ajustes que de una u otra forma dieron origen al desencadenamiento de fundamentalismos. En el caso islámico coincidió con el establecimiento del Partido de Salvación Nacional de Turquía en 1973. En Irán, seis años después, el fundamentalismo chií logró la victoria con la Revolución Islámica; responsable de deponer al gobernante prooccidental miembro de la longeva dinastía, el Sha Reza Pahlavi. La proclamación de la República Islámica de Irán, en Teherán, aconteció justamente en el año cuando daba inicio el siglo XV del calendario musulmán.

Con el arribo del Ayatolá Jomeini en Irán se inició un gobierno con un alto predominio de una casta sacerdotal con gran influencia con el poder del veto; como la encargada de aprobar los candidatos a la presidencia. De la gestión del nuevo dignatario iraní destaca su ímpetu por rescatar los lugares santos materializado en el asalto de la mezquita de La Meca por parte de un grupo armado. En criterio del Ayatolá era inconcebible que los saudíes, entregados completamente a Occidente, por su vínculo con los Estados Unidos, controlaran sitios de respeto y de veneración para el Islam. Este hecho acaparó la atención de la opinión mundial porque se puso de manifiesto el potencial contenido en una decisión proveniente de un líder fundamentalista.

Siguiendo a Kienzler (2011), otro gesto de Jomeini también fue noticia internacional; se trató de una afrenta en contra de un escritor dirigida por parte del líder iraní ocurrida en 1988. Salman Rushdie, un escritor inglés de origen indio con raíces islámicas; era el autor de Los versos satánicos y por ello se le catalogaba como artífice de lanzar blasfemias en contra del profeta Mahoma. Así lo consideraban grupos fundamentalistas pakistaníes. Por su parte, el Ayatolá asumió la causa como suya y ordenó la ejecución de Rushdie mediante la promulgación de una fatwa, opinión legal con carácter de acatamiento obligatorio. Era, según Kienzler (2011), la oportunidad de Jomeini de levantar la bandera de la Guerra Santa (yijad) al campo internacional y además era el pretexto buscado para recuperar lo perdido frente la guerra entre Irán contra Irak, un conflicto armado acaecido durante el decenio de 1980.

La proyección internacional del asunto Rushdie caló también en el subcontinente indio, donde Jomeini patrocinó la desestabilización de la región. Durante la década de 1970, mientras en 1979 triunfaba la Revolución Islámica, la Unión Soviética invadía Afganistán, tal como se observó en el apartado anterior. A partir de este hecho el islamismo radical, en su versión fundamentalista, fue más que evidente en su ascenso. Pese a que Occidente no tuvo la capacidad de percatarse de ello.

Los Estados Unidos prestaron colaboración de armas y de dólares a los mujadines que lucharon en contra del enemigo soviético, que a lo largo de más de treinta y cinco años de conflicto desde 1979, ha visto pasar por su suelo más de 35.000 militares islamistas. Simultáneamente, Afganistán se convirtió en un "conflicto que activó el mito movilizador y a la vez de gran causa común de los fundamentalistas de todo el mundo musulmán, quienes acudieron a luchar en una nueva guerra santa. La guerra de Afganistán constituyó esa experiencia formativa” (Núnez, 2015, p. 287). 
De esta forma, la radicalización fundamentalista cobró un nuevo brío porque

"En el transcurso de la década de 1980 un importante número de movimientos islámicos decidiría poner en marcha una lucha armada, ya fuera para derrocar a sus dirigentes laicos o para repeler a los invasores extranjeros. Los islamistas esperaban establecer un Estado islámico gobernado con la sharía, una ley que según su firme creencia era la ley de Alá" (Rogan, 2010, p. 680).

En esta dinámica, Washington se valió del islamismo fundamentalista en contra de los soviéticos al prestar ayuda solapada a través de sus aliados musulmanes: Arabia Saudí, Egipto, Marruecos y Pakistán. Para el gobierno estadounidense, la acción fundamentalista constituía un importante aliado para contribuir en la desestabilización de las repúblicas musulmanas de Asia Central que para ese entonces estaban en manos soviéticas. En esos mismos años, según indica Fontana (2011), el director de la CIA, William Casey, ordenó imprimir miles de ejemplares del Corán en lengua uzbeka para su distribución en Afganistán, esto para tratar de fomentar el islamismo y así levantar los ánimos religiosos en contra del poder comunista laico gobernante.

En el caso específico de Pakistán, que fue a todas luces un "experimento islámico moderno", según Armstrong (2013); el fundamentalismo estaba íntimamente vinculado al nacionalismo musulmán; e hizo posible la creación misma de un Estado independiente de la India en 1947 bajo la égida de Muhammad Ali Jinnah. Mucho tiempo atrás desde la época del dominio británico, los ulemas -que en árabe se traduce como juristas y sabios- desempeñaron un importante papel en la enseñanza del Corán alrededor de la organización de las dini madrasas, escuelas dedicadas a la enseñanza de la doctrina.

En el siglo XVIII surgió en la India un movimiento conservador y austero llamado deobandi, cercano al wahabismo, portador de la consigna de formar ulemas capaces de emitir fatwas, pronunciamientos legales rigoristas y conservadores apegados al Islam, encargados de regir todos los aspectos de la vida cotidiana. El resultado no se hizo esperar: al cabo de unos cien años, se emitieron cientos de miles de fatwas. El movimiento de los deubandis pakistaníes, portador de la lucha contra Occidente, creció en número y en importancia al grado de empezar a presionar a las autoridades a fin de incorporar los principios islámicos en la legislación.

El control de los deobandis se ejercía predominantemente en las escuelas coránicas concurridas por jóvenes provenientes de hogares rurales y urbanos de bajos recursos. Este movimiento también propugnó en favor de que el Estado solo contratara a los egresados de sus escuelas. Pakistán se independizó en este contexto de influencia creciente de los deubandis. Diferentes partidos políticos estaban en pugna por islamizar el país; mientras tanto, las elites occidentalizadas promovían su laicización.

Sin embargo, en el criterio de Kepel (2002), la acción persistente de los ulemas resultó victoriosa en la tarea de forjar el nacionalismo musulmán; fue la fundadora de Pakistán:

"Sin el Islam, Pakistán no podía existir: nada justificaba su existencia. Al margen de la India y lo que mantenía la unión de los pueblos que lo componían pashtús y sindhis, pendjabis y balushis y refugiados provenientes de la India” (Kepel, 2002, p. 128). 
Para la década de 1970, el partido Mawadi pakistaní constituido por los ulemas, era una fuerte fuerza política y contaba con presencia en los espacios tradicionales; al mismo tiempo, la población aumentaba rápidamente. Poco a poco los jóvenes empezaron a identificarse con una retórica basada en las enseñanzas obtenidas en sus escuelas islámicas que recogían las reivindicaciones de un país golpeado por el aumento de los precios del petróleo y por la severa crisis ocasionada por la explosión demográfica; para 1978 alcanzaba los 78 millones de habitantes, luego de contar en 1960 con 45 millones (Sathar, 2001). Dos años después del arribo del general Zia ul-Haq, en 1979, se instauró la sharia, y de paso, este dignatario brindó apoyo a yihadistas afganos.

A partir de los años ochenta, la situación pakistaní se puede resumir en cinco aspectos: a) las constantes amenazas por parte de la India, con quien había librado guerras en el pasado; b) la instauración de un régimen militar dictatorial puesto en entredicho por las disputas y los escándalos de corrupción entre los sectores dominantes, incluyendo las acusaciones de blanqueo de dinero por parte de la primera ministra Benazir Bhutto; c) la inestabilidad política, proyectada más allá de esa década con el asesinato de la líder Bhutto en diciembre de 2007; d) el conflicto étnico asociado a la complicidad en la conflagración bélica afgana a partir de la participación de la población pashtun que fue, a su vez, trastocado en su hegemonía interna a partir del establecimiento del gobierno comunista laico; y e) el apoyo local de los pashtunes a los mujahidines afganos, los guerreros con una clara tendencia fundamentalista que repudiaban el poder ejercido con sede en Kabul y la ocupación extranjera encarnada por el Ejército Rojo; al respecto se ha señalado a Pakistán como promotor del ascenso talibán en Afganistán; mientras tanto Occidente miró a los talibán como un régimen que posibilitaría una especie de reedición del "Gran Juego" para así ejercer un control de las riquezas de Asia Central (Bearden, 2002).

En este Gran Juego contemporáneo se supone "una nueva competición por ganar influencia, poder, hegemonía y beneficios en relación con las reservas y las industrias petrolíferas y gasísticas de la zona (Sánchez, Mañé, de la Cámara y Huici, 2013, p. 22).

De acuerdo con lo señalado por Zéraoui (2009), para inicios del siglo XXI, la situación interna y externa pakistaní se puede caracterizar por los aspectos siguientes: constituido por una población predominantemente sunní (77\%), presionado en el norte por los rebeldes afganos y al este enfrascado en el conflicto con la India por Cachemira. Parafraseando a Jaffrelot (2002), una forma válida de describir a Pakistán es como un corazón de tensiones étnicas y de conflictos regionales.

En medio de este intrincado ajedrez, el conflicto afgano perfiló el destino de Pakistán como un territorio cruce de tensiones regionales, como lo afirma Jaffrelot (2002), porque además de la participación de la etnia pashtun, estableció un maridaje con las intenciones de Washington, al principio con Carter y luego con el nuevo espaldarazo brindado por Ronald Reagan, con su férrea doctrina anticomunista para el pertrecho de tropas que aseguró el envío de dinero a raudales para luchar en contra de la expansión por parte de la Unión Soviética, a quien el mismo Reagan trataba como el "Imperio del Mal".

En 1987 aterrizó en el centro de resistencia islámica antisoviética por antonomasia, en Peshawar, Osama Bin Laden, un millonario saudí que creció bajo la influencia wahabista, hijo de una familia dedicada a la construcción especializada en la edificación de mezquitas para el clan Saud. Su promesa consistió en colaborar, de la mano de la CIA con los Servicios de Inteligencia Pakistaníes (ISI) en favor de encarrilar su apoyo a los señores de la guerra afganos favorables a Pakistán. 
Dentro de este escenario, Peshawar se erigió como el núcleo de operaciones donde se entremezclaba el financiamiento saudí, el armamento financiado por la Casa Blanca y el tráfico de estupefacientes bajo la iniciativa de la CIA, con la entera participación del ISI. Esta ciudad de frontera fue la cuna de formación de los cuadros de los dirigentes del islamismo radical e internacional.

Washington apoyó al Partido Islamista Pakistaní Jamaat i Islami fundado por al-Mawdudi, un fundamentalista sunní deseoso de introducir la sharia en todo el orden social y propulsor de un proyecto de "teología de la liberación islámica" (Armstrong, 2013). El Gobierno pakistaní coadyuvó en soliviantar en los refugiados afganos, que ascendían a los cuatro millones, el deseo de reclamar su país a los comunistas, mediante el arrebato armado en el nombre de Dios.

Quienes tenían las riendas de Estado pakistaní, estaban organizados en el Partido Democrático del Pueblo Afgano (PDPA), fundado en 1956, encargado a su vez de conducir la "Revolución Ilustrada", tal como lo considera Segura (2001), mediante una agresiva campaña de alfabetización y por medio de una reforma agraria, en aras de mejorar los rendimientos agrícolas y hacerle frente al desempleo. Por otro lado, Pakistán deseaba la instauración de un gobierno fundamentalista de índole sunní en su país vecino. Era también una estrategia, que en el plano geopolítico, tenía su explicación en la atención pakistaní de contar con una vía directa de acceso al Asia Central.

Como se observó con antelación, en 1989 sucedió el fracaso de Shevarnadnaze, el ministro de Asuntos Exteriores en su afán de lograr una tregua en Afganistán a partir de la retirada de las tropas. El ISI y la CIA rechazaron la propuesta provocando, indirectamente, la caída del gobierno de Kabul en manos de los rebeldes. En ese mismo año, los señores de la guerra, enfrentados entre sí, lucharon por librar al país del régimen comunista y se dio origen a una guerra civil; seis años después, en setiembre 1996 con la toma de la ciudad capital, los talibán ejecutaron al expresidente comunista Nayibullah y se convirtieron en los dueños del poder de una importante parte del territorio con excepción de las poblaciones uzbekas y tayicas. En 1997 ese movimiento islamista talibán fundó el Emirato de Afganistán, quedaba atrás así la experiencia de la república.

En términos internacionales según lo indica Segura (2001), los talibán, un movimiento islámico sunní conservador pero no revolucionario, fue considerado por la Casa Blanca y por Islamabad como la opción de recambio político basado en la hegemonía pashtun, por la incompetencia de del partido de Hekmatyar de obtener la pacificación y estabilidad, atribuida a su convicción de echar a andar un modelo político más moderno. Además una vez desaparecida la URSS, Afganistán se había convertido en un enclave geoestratégico para la raigambre de intereses de los Estados Unidos de Arabia Saudí y de Pakistán.

Tómese en cuenta los recursos energéticos existentes en Asia Central; además de constituir una importante ruta para el petróleo y del gas natural. Afganistán se perfilaba como una vía alterna a la del Golfo Árabe-Pérsico y a las del control iraní; esta es la esencia del "Gran Juego" basado en la batalla de los poderes, remontada al siglo XIX, por el dominio de los recursos de la región; en este caso más contemporáneo comprende el control de los oleoductos y gaseoductos que cruzan Afganistán (Rashid, 2001). No obstante la atención de Washington por la guerra civil propiamente dicha en Afganistán, decreció y el conflicto como tal corrió la suerte de la orfandad; dejó de ser relevante para la comunidad internacional. 
George H. W. Bush había volcado su interés a los sucesos ocurridos en Europa apropósito de la apertura del Muro de Berlín y luego con la Guerra del Golfo. No obstante, no debe pasarse por alto que desde décadas anteriores:

"La implicación de Washington contenía cierta dosis de hipocresía y de cinismo, que contribuyó a forjar, en el mundo árabe e islámico una actitud de desconfianza y de recelo hacia la política exterior de la Casa Blanca, actitud que fue reforzada, años más tarde, con el con el "Iran-gate" (...) En efecto, en la década de los ochenta, Washington fue capaz de apoyar al mismo tiempo, a Sadam Hussein en la guerra contra Irán y a los muyajidín de Afganistán" (Segura, 2001, p. 364).

Como se ha insistido, dentro de este escenario, Pakistán no se vio librado de los embates de la guerra que embargó a Afganistán; máxime si se toma en cuenta el irredentismo renovado para reclamar las tierras pashtunes. Solo en dos años, entre 1979 y 1981 se establecieron 2,4 millones de afganos en las tierras de Peshawar (Jaffrelot, 2002). Para 1989, el saldo de la guerra fue atroz: un millón de afganos perdieron la vida; diez años después se contabilizaban cinco millones de drogadictos; era el resultado de la estrategia de estadounidense, facilitada por la CIA, de suministrar opio a los soviéticos en el campo afgano.

Afganistán había incrementado considerablemente la producción del estupefaciente con respecto a 1998. Se configuró así una compleja red de cultivo y distribución de drogas integrada por Irán, Afganistán y Pakistán denominada por Cooley (2002) como la "Media Luna de Oro". Por otro lado, Osama Bin Laden se refugió en Pakistán -luego de haber vivido por años en Afganistán y en Sudánbajo la supuesta complicidad de los servicios secretos del ISI.

Durante casi un decenio permaneció en una zona montañosa hasta su captura en su escondite en Abbottabad en 2011. Esto luego de que inmediatamente después de los atentados del 11 de setiembre de 2001, los Estados Unidos y sus aliados decidieran invadir y arrasar Afganistán, mediante la Operación Libertad Duradera, país donde se presumía el paradero de Bin Laden, quien a su vez, era el protector de los talibán, amigo cercano del mullah Omar, y por sobre todo, el responsable en calidad de autor intelectual del acto terrorista, según Washington. Tómese en cuenta que los Estados Unidos desde 1999 miraban con reticencia al gobierno totalitario teocrático de los sunníes talibán, otrora de su confianza, por no haber complacido sus deseos en reducir el cultivo de opio.

Así con ocasión de los atentados del 11 de setiembre, los Estados Unidos declararon la guerra contra el terrorismo y a partir de octubre del mismo año, inició la invasión a Afganistán con el decidido apoyo pakistaní interesado en congraciarse con Washington. Era impostergable llegar a detener a Osama Bin Laden que estaba escondido en las montañas de Tora Bora al este de ese país. Empero, como lo indica Rogan (2010), las tropas de Occidente no llegaron a los paraderos de Bin Laden ni al del Mullah Omar, el cabecilla talibán.

En la década anterior, no hubo un acompañamiento de la Casa Blanca luego de que se instaurara un nuevo orden político, esta vez presidido por Hamid Karzai. Como corolario de este "descuido", producto de las intenciones de los estadounidenses por hacerle la guerra a Irak, los enfrentamientos afganos se han prolongado por más tiempo y parece no estar cercano del día de la eliminación completa del control talibán. 
Una vez abordados los temas anteriores queda pendiente aportar una definición de fundamentalismo, entendido entonces como aquella corriente del Islam originada en los sectores medios en procura de consolidar la creación del Estado Islámico. Se apela a la restauración de un Estado en razón de su interés en resaltar y rescatar las grandezas del califato fundado luego de la muerte del profeta. En el Islam, la religión y la política no están separadas; el fundamentalismo, por su parte, aspira a volver a las fuentes primigenias del Islam, a la ley revelada denominada sharia, interpretada por los muftí, los jurisconsultos musulmanes. Esto en oposición directa a la bid'a (innovación). Para llevar a cabo la implantación de la sharia, un instrumento fundamental es

"La doctrina de la yihad, la "guerra santa", como medio de parcial realización de la vida islámica en la comunidad, correspondía a la creencia fatalista en la predestinación: la promesa de la entrada inmediata en un paraíso, descrito muy sensualmente, como premio garantizado por la muerte en la lucha por la fe, daba a la doctrina del Islam una gran fuerza ofensiva de combate" (Maier, 1989, p. 271).

De acuerdo con lo señalado por Marín (2002) y (2005), dentro del fundamentalismo islámico, como doctrina y como movimiento de renovación religiosa, se pueden identificar tres tensiones básicas que pueden ser de utilidad para comprender sus manifestaciones más radicales en el mundo contemporáneo.

- La tensión trascendencia-inmanencia de Dios que tiene su reflejo más inmediato en que la sociedad debe estar sometida a las autoridades de la misma forma en que el ser humano está sometido a la divinidad.

- La tensión diversidad-unidad que aboga en favor de la unidad de la umma (la comunidad primigenia) data de los tiempos cuando el profeta se puso de acuerdo con sus seguidores acerca de las obligaciones y los derechos de una comunidad única. Cualquier desviación va en menoscabo de la integridad de la umma.

- La tensión de lo ajeno versus lo autóctono que está presente en el interés de no aceptar la innovación proveniente de otras culturas. No obstante en sus primeros siglos de conquista, el Islam se había caracterizado desde la época de su expansión temprana por incorporar elementos de los más variados orígenes, que no entraran en contradicción con el Islam.

A tenor con lo señalado por Marín (2002) y (2005), además de las tensiones anteriores, los movimientos fundamentalistas han sido fruto de una reacción ante los modelos secularistas y globalizantes de inspiración occidental, que muchas veces han humillado a la umma, y a la acción poco inclusiva de los gobiernos locales, muchas veces apadrinados por potencias de Occidente. Las cargas acumuladas de tensiones alcanzaron su punto más alto a partir de la invasión de la Unión Soviética a Afganistán, esta se constituyó, a su vez, en la fase formativa que operó como un catalizador en el desarrollo del terrorismo contemporáneo posterior, en que se confluyeron las posiciones fundamentalistas encarnadas por Aiman al-Zawahiri -quien a su vez era discípulo de Qutb-y, el líder del partido islamista pakistaní, al Mawdudi.

Además de los atributos anteriores, deben destacarse otros que en el criterio de Armstrong (2013), por su relevancia no se pueden dejar pasar por alto. Quizá todo se origina en el punto de que el fundamentalismo, como hecho universal, está presente en diferentes religiones y que además no es monolítico; hay fundamentalismos en plural y una sola manifestación que englobe a todas las demás. 
Todos los fundamentalismos confluyen en compartir una decepción acerca del saldo de la modernidad en cuanto a sus realizaciones. Los modelos occidentales exportados a diferentes países con realidades sociales diversas; en su mayoría estos patrones descansan en los valores del capitalismo, de la laicidad y de la democracia; sin embargo su implementación -si es que ha ocurridono se ha traducido en mejoras sustanciales para los habitantes de esos países.

Ante los fundamentalistas, parece que Occidente se ha reservado para sí el disfrute exclusivo de los beneficios de la modernidad. De ahí que sean severos críticos de los pilares occidentales básicos. En el caso específico musulmán, sus posiciones se han radicalizado a partir del decenio de 1970 dando lugar a movimientos más agresivos y violentos, que sin ser la mayoría, han portado la bandera de la transformación total de la sociedad, como lo fue su realización máxima cuando el fundamentalismo shií derrocó al sha gracias a la revolución triunfante en 1979.

Siguiendo a la misma autora, debe advertirse el hecho que los talibán no deben ser asumidos "como musulmanes en estado puro". Ante todo es un grupo fundamentalista del islam que arribó al poder afgano en 1994; sin embargo no comulgan en todo con lo dispuesto por el profeta, entre esos puntos de separación con la doctrina destacan las prácticas xenofóbicas ejercidas por parte de los pashtunes en contra de los otros grupos étnicos de la región. Así, "Como sucede en todas las grandes religiones, los fundamentalistas, convierten su fe en un instrumento de opresión e incluso de violencia" (Armstrong, 2013, p. 184).

De esta manera, el mundo pakistaní de Malala sería difícil de comprender si se obvia la cadena de acontecimientos, vinculados con el ascenso fundamentalista desencadenado luego de diciembre de 1979, cuando, indirectamente, la llegada del contingente soviético provocó el fin de la hegemonía pashtun junto con el equilibrio relativo de los distintos grupos étnicos presentes en el mundo afgano.

\section{La historia vivida de Malala}

Como un grito de auxilio, con ocasión de la elaboración de un documental, la joven Malala expresó que los talibán "No pueden detenerme. Voy a formarme, tanto si es en casa, en la escuela o donde sea. Esto es lo que pedimos al mundo: que salve nuestras escuelas, que salve nuestro Pakistán, que salve nuestro Swat" (Yousafzai, 2013, p. 180).

Malala nació en Pakistán en 1997, un país con 180 millones de habitantes cuyo nombre quiere decir: "tierra pura". Fundado por Jinnah, a quien por cierto el padre de la joven Premio Nobel le atribuye el mérito de crear un territorio, mas no un Estado (2013). A lo largo de la historia este Estado ha tenido que debatirse en medio de las amenazas de guerra de la India (en total ha librado tres grandes conflictos bélicos con el país del que se separó en 1947); además de las amenazas de guerra civil, producto de su endeble estabilidad política. Ha presenciado la tendencia a los regímenes militares autoritarios, receptores de cuantiosos recursos económicos provenientes del extranjero para combatir el terrorismo, pero que no se traducen en bienestar para las gentes.

Estos Gobiernos han sido poco interesados en dotar de agua potable, del saneamiento a una gran parte de la población, de hacer frente al analfabetismo manifiesto en 50 millones de habitantes y de dar solución a la hepatitis que golpea a uno de cada siete de los infantes. Por último, la posición geopolítica de Pakistán ha comprometido su territorio debido al estallido de la guerra de Afganistán 
El mundo de Malala: Una historia...

iniciada en 1979, como se observó con antelación. Seguidamente se muestra un cuadro acerca de las regiones pakistaníes. 


\section{Tabla 2 \\ Regiones de Pakistán}

\begin{tabular}{|c|c|}
\hline Nombre & Características \\
\hline Punyab & $\begin{array}{l}\text { La provincia con mayor cantidad de población ( } 88 \text { millones). Los } \\
\text { punyabíes son el grupo étnico predominante. Se asienta en una rica } \\
\text { cuenca aluvial. Es una región agrícola e industrial por excelencia. }\end{array}$ \\
\hline Sind & $\begin{array}{l}\text { Ubicada en el curso bajo del Indo, depende de obras de regadío } \\
\text { para el desarrollo agrícola. } \\
\text { Habitada sobre todo por sindis y mujayires (refugiados procedentes } \\
\text { de la India). El puerto de Karachi es la capital de la provincia, la } \\
\text { ciudad más importante en industria y comercio. }\end{array}$ \\
\hline Baluchistán & $\begin{array}{l}\text { La más extensa en territorio, allí viven solo unos } 8 \text { millones de } \\
\text { habitantes. En su mayoría se ubica en un altiplano árido con una } \\
\text { de las reservas de gas natural más importante del mundo. }\end{array}$ \\
\hline $\begin{array}{l}\text { Frontera } \\
\text { Noroeste }\end{array}$ & $\begin{array}{l}\text { La más pequeña en territorio. El grupo étnico predominante es el } \\
\text { pashtun. Junto con las FATA libran una batalla contra el } \\
\text { extremismo religioso. }\end{array}$ \\
\hline \multicolumn{2}{|c|}{$\begin{array}{l}\text { Además, existen cuatro áreas separadas o autónomas, de administración del } \\
\text { gobierno federal }\end{array}$} \\
\hline 1. Islamabad & La capital federal \\
\hline $\begin{array}{l}\text { 2. Cachemira } \\
\text { Azad }\end{array}$ & $\begin{array}{l}\text { Bajo control pakistaní. Su estatus final depende de un plebiscito } \\
\text { de la ONU. }\end{array}$ \\
\hline $\begin{array}{l}\text { 3. Regiones del } \\
\text { Norte }\end{array}$ & Violencia y derramamiento de sangre. \\
\hline $\begin{array}{l}\text { 4. Áreas tribales } \\
\text { administradas } \\
\text { federalmente }\end{array}$ & $\begin{array}{l}\text { Ubicadas en la frontera noroeste y Afganistán. Se han convertido } \\
\text { en refugio de extremistas islámicos. }\end{array}$ \\
\hline
\end{tabular}

Fuente: Elaboración propia a partir de Bhutto, B. (2008).

Malala es una habitante pashtun de Mingora, poblado ubicado en el valle intermontano de Swat rico en la producción de arroz, melocotones e higos. Situado en la región del noroeste de Pakistán donde se asienta una importante presencia de población pashtun (en la región denominada como Khyber Pakhtunkhwa). Los pashtun son uno de los grupos étnicos de Pakistán que comparten el área fronteriza con Afganistán; existen pashtunes en ambos países, como se observó con anterioridad. 
Malala narra su niñez con un cierto tono de vida apacible; sin embargo, todo cambió cuando cumplidos sus cuatro años, el 11 de setiembre de 2001 sobrevino el atentado terrorista que derribó el símbolo por excelencia del capitalismo en los Estados Unidos, las torres gemelas de Nueva York. Fue "el más dramático de los acontecimientos recientes, en términos de repercusión mediática, sino por la suma de sufrimiento y pérdidas humanas” (Ruthven, 2008, p. 549).

En palabras de Rashid (2001), dicho evento ocurrió luego que

"Desde 1989, Estados Unidos y Occidente vienen dando la espalda a la prolongada guerra civil de Afganistán. El 11 de septiembre de 2001, el mundo dejó de ser el mismo cuando Afganistán se mostró ante el mundo de una manera brutal y trágica "(p. 11).

Para esa niña, que escuchó dicha noticia por boca de un allegado a la familia, ese acontecimiento tan local ubicado al otro lado de su mundo, cambió para siempre la historia de su país porque la implicación posterior de Pakistán en el conflicto que devendría, llegó a ser decisiva. Recuérdese que Osama Bin Laden, avanzados los años ochenta, había aterrizado en suelo pakistaní cargado de armas para surtir a los mujahidines, las fuerzas combatientes en contra de los soviéticos; desde 1984, empezó la tarea de reclutar islamistas de todo el mundo.

En Afganistán durante esos años, se esmeró en encausar los esfuerzos de los islamistas a campañas de levantar orfanatos y casas para viudas en el este del país; además edificaba carreteras y búnkers (Bearden, 2002). Su objetivo no era solo organizar "una guerra contra Moscú: es sobre todo una guerra de afirmación del islam frente a sus enemigos de dentro y de fuera" (Esparza, 2015, p. 296297). Bin Laden era un disidente saudí, miembro de la yihahista Unión Islámica, discípulo del ulema palestino Abdullah Assam y, además, fiel creyente de la doctrina wahabista. Era usual que algunos dirigentes pashtunes reconocieran a Bin Laden como un héroe; en palabras de Malala:

"En el mercado se vendían posters de él sobre un caballo blanco y cajas de dulces con su retrato. Los clérigos decían el 11-S era la venganza por lo que los estadounidenses hacían a otra gente en todo el mundo" (Yousafzai, 2013, p. 99).

Para Malala, su vida cotidiana como estudiante comenzó a tornarse difícil a partir de la transmisión de frenéticos mensajes radiofónicos emitidos por el estudioso islámico opuesto al gobierno de Pakistán, el maulana Fazlullah, un hijo del Sufi Mohammad, quien fundó un movimiento en favor de la aplicación de la ley islámica en 1992. Incitaba a los padres de familia a no enviar a sus hijas a los centros de enseñanza. En su programa de radio empezó a hacer públicos nombres de alumnas: " $L a$ señorita tal ha dejado la escuela e irá al paraíso - decía $O$ - : La señorita tal ya no va al colegio y yo felicito a sus padres" (Yousafzai, 2014b, p. 62).

Ante tales manifestaciones, Malala preguntaba a su padre del porqué de estas declaraciones y la respuesta fue

"Que la vida era aún peor para las mujeres en Afganistán, donde un grupo llamado "talibanes" se había apoderado del país. Habían quemado los colegios de niñas y todas las mujeres estaban obligadas a llevar una forma rigurosa de burka, un velo que cubre desde la cabeza a los pies y que sólo deja una pequeña rejilla para los ojos. A las mujeres se les había prohibido reírse alto o pintarse las uñas y se les encarcelaba o golpeaba por salir a la calle sin ir acompañadas de un miembro masculino de la familia” (Yousafzai, 2014b, p. 37). 
La condición de la mujer empezó a ser minimizada por parte de los talibán y de los maulana. Fazlullah no tuvo reparo en aplicar castigos a quienes desobedecían

"Había creado un tribunal público para hacer cumplir sus edictos, y sus hombres azotaban o asediaban a policías, funcionarios del gobierno y otros hombres y mujeres que desobedecían. Se reunían cientos de personas para presenciar las flagelaciones gritando “;Allahu Akbar! "Dios es grande”, con cada latigazo. Según se decía, Fazlullah se presentaba allí a veces montado en un caballo negro” (Yousafzai, 2014b, p. 63).

Fazlullah era dirigente del Tehrik-e-Nifaz-e-Sharia-Mohammadi, un movimiento en favor de la aplicación de la ley islámica. Fazlullah era un maulana que emitía fatwas, opiniones jurídicas autorizadas sobre un sinnúmero de asuntos de la vida cotidiana. Kepel (2002) había constatado este tipo de actividad que normaba la vida social en Islamabad y en Karachi en 1998. En ese momento, Malala contaba escasamente con un año de edad.

En opinión de Malala, al cabo de diez años, Mingora se empezó a convertir en una prisión caracterizada por una ola creciente de desaparecidos. El mismo Fazlullah había amenazado de muerte al padre de la furtura Premio Nobel quien era propietario de escuelas. Esto pese a la rúbrica de un tratado de paz con un nuevo grupo dueño del poder en Afganistán, los talibán. Se había negociado el cese del fuego a cambio de que se impusiera la sharia, la ley islámica. No obstante, en 2007 se alcanzó la cifra de al menos 1000 asesinatos acompañados de destrucción de infraestructura. Al año siguiente, justo en el mes del Ramadán, mandaron por los aires la central eléctrica de Swat.

El resultado de la precaria situación del país es más que evidente en la desnutrición en la población infantil y la propagación de enfermedades infectocontagiosas. Las mujeres fueron confinadas al purdah; al uso estricto del velo y a su aislamiento de la esfera pública. Quienes de ellas se arriesgasen a asistir a la escuela corrían el riesgo de que les derramaran ácido en sus rostros. Según sostiene Rashid (2001), para las postrimerías del siglo XX, "Paquistán, Arabia Saudí y los estados del golfo Arábigo nunca han hecho una sola declaración sobre la necesidad de la educación femenina o de que los derechos humanos estén vigentes en Afganistán" (p. 187).

En el criterio de Malala, lo anterior apunta a una "talibanización privada". Como se observó con anterioridad, la aparición de los talibán fue una consecuencia directa del conflicto librado en Afganistán, prometían la paz y llegaron a imponer un orden en medio del caos a partir de la imposición de la sharia. A lo largo de sus escritos, Malala, se refiere a los talibán de la manera en que se muestra en el cuadro siguiente. 


\section{Tabla 3}

\section{Características de los talibán según Malala}

\begin{tabular}{|l|l|}
\hline \multicolumn{1}{|c|}{ Característica } & \multicolumn{1}{c|}{ Descripción } \\
\hline Origen & $\begin{array}{l}\text { Mayoritariamente son de origen pashtun, la etnia predominante de } \\
\text { Afganistán. Concentrada sobre todo en el sur y el este, y el noroeste } \\
\text { de Pakistán, donde son el segundo grupo étnico en número. }\end{array}$ \\
\hline Control geográfico & $\begin{array}{l}\text { El valle de Swat, donde habita Malala, es la región más } \\
\text { conservadora de Pakistán, un territorio intermontano habitado por } \\
\text { pashtunes y controlado por los talibán. }\end{array}$ \\
\hline Interés & $\begin{array}{l}\text { Al igual que lo hicieran gobiernos afganos anteriores, so pretexto } \\
\text { del arrebato que les hiciera la India bajo el dominio británico; los } \\
\text { talibán reclaman los territorios habitados por los pashunes en } \\
\text { Pakistán, sobre todo en el noroeste. }\end{array}$ \\
\hline Propuesta & $\begin{array}{l}\text { El líder sufí Mohammed, había propuesto que a cambio de la } \\
\text { imposición de la sharia en Swat, se librarían de la violencia de los } \\
\text { talibán que acompaña a los enfrentamientos. }\end{array}$ \\
\hline
\end{tabular}

Fuente: Elaboración propia a partir de Yousafzai, M. (2013)

El grado de violencia de Pakistán fue in crescendo, principalmente bajo el gobierno matizado de posturas occidentalizadas presidido por un dignatario que arrebató el poder su predecesor electo constitucionalmente, Pervez Musharraf (2001-2008). Su deseo consistió en lograr un acercamiento con la Casa Blanca en su cruzada antitalibán; pese a que resulta paradójica su responsabilidad en el auge talibán afgano. Sin embargo, en su país hacia 2007 los talibán presionaban en noroeste del país, los militares provocaron desórdenes en la ciudad capital de Islamabad, con ocasión de un conflicto desarrollado alrededor de una mezquita, encabezado a su vez por líderes fraguados en Cachemira y en Afganistán.

En ese mismo año se decretó el estado de excepción. Esta inestabilidad ha puesto sobre el tapete la fragilidad del Estado Pakistaní, en el criterio de Menon (2002) se corre el risgo de agudizar una serie de tensiones enmarcadas en una historia violenta producto de una "mezcla explosiva" de factores relacionados sobre todo por la particularidad de su tejido social.

En medio de este contexto, la familia de Malala decidió salir de su ciudad natal, Mingora, hacia un viaje con un itinerario variado: Peshawar, Mardan y Abbottabad, entre otros destinos. Este viaje, semejante al éxodo bíblico; fue tortuoso y además constituyó una de las etapas más duras de la vida de la protagonista, 
Normalmente hay muchas carreteras para salir de Mingora pero los talibanes habían cortado varios grandes manzanos y bloqueaban algunas rutas, por lo que todos nos hacinábamos en la misma carretera. Éramos un océano humano. Los talibanes patrullaban las carreteras con armas y nos vigilaban desde lo alto de los edificios (Yousafzai, 2013, p. 200).

De paso, Malala junto con los suyos trataron de poner en conocimiento al resto de la sociedad pakistaní de lo sucedido en el noroeste del país. Desde ahí su condición familiar cambió drásticamente: se convirtieron en desplazados dentro de su mismo Estado (PDI).

Tiempo después solo la mitad de la población se devolvió a sus hogares de Swat, el otrora espacio geográfico lleno de grandes atractivos turísticos como sus cascadas, lagos, estaciones de esquí y estatuas de Buda; había dado paso a un valle de las desgracias portador de muerte. Para el padre de Malala, la población común estaba aterrada por el terror generado; enfrascada en un conflicto entre el ejército y los talibán: "Mi padre decía que la gente corriente éramos como paja atrapada entre las piedras de un molino" (Yousafzai, 2013, p. 171).

Cuando la familia de Malala regresó a su casa, Mingora estaba en ruinas producto de la destrucción ocasionada por la guerra, originada al principio en el noroeste del país, entre los talibán y los miembros del ejército. Estos últimos encargados de operaciones militares como la Camino Verdadero orientada a la liberación de regiones controladas por los talibán. La sociedad se había militarizado; el ejército multiplicaba por siete el gasto dedicado a educación, había emprendido una campaña publicitaria alusiva a la defensa realizada durante las guerras contra la India; además había diversificado sus actividades: eran propietarios de fábricas de fertilizantes, de palomitas de maíz y de empresas productoras de series de televisión.

Sin embargo, el saldo de este enfrentamiento resultó desolador:

"Adonde quiera que mirásemos veíamos edificios en ruinas, montones de cascotes, coches quemados y cristales rotos. En las tiendas habían forzado las presiones metálicas; las ventanas estaban arrancadas, los anaqueles vacíos. Parecían que los edificios estaban marcados por una viruela de agujeros de bala" (Yousafzai, 2014b, p. 122).

Luego sobrevino otra desgracia. Entre julio y agosto de 2010, sucedió un desastre natural que dio muerte a unas dos mil personas, una inundación causada por el desborde del sistema hídrico de los ríos Swat e Indo; este último reconocido desde tiempos inmemoriales, irriga una las más fértiles llanuras del mundo. La crecida sin parangón de las aguas causó el brote de la epidemia del cólera y, al mismo tiempo, la carencia de agua potable y de electricidad.

El monzón fue el responsable de inundar todo el valle y la respuesta de los líderes fundamentalistas fue una filípica sentencia: "Dios había enviado un desastre natural como castigo por los comportamientos antiislámicos” (Yousafzai, 2014b, p. 127).

Casi cuatro años y medio antes de la gran inundación aconteció la devastación del terremoto de octubre de 2005 que provocó casi 75000 muertos, con el consiguiente desvío de la ayuda internacional por parte del gobierno. Ante estos dos desastres naturales voluntarios pertenecientes a grupos islámicos tendieron la mano a los damnificados. 
El ámbito político, estuvo marcado por el asesinato de Benazir Bhutto líder del Partido del Pueblo de Pakistán, en medio de un mitin electoral. El desarrollo de un conflicto aún más complejo también es parte de la realidad del país en donde los equilibrios en el poder han sido endebles

La coyuntura de la guerra contra el terrorismo vino a fracturar el consenso interno del bloque del poder y los pilares de la relación islamismo-Estado. Desde entonces, el ideal de la yihad impulsado en el pasado por los intereses geopolíticos de Pakistán, ha derivado en una guerra interna del islamismo radical contra un Estado que, por conveniencia o necesidad, aparenta ahora adjurar de su "identidad islámica" (Baltar, 2012, p. 672).

Con el arribo de los talibán, con sus posiciones fundamentalistas se saquearon piedras preciosas y maderas para financiar la compra de armas, para Malala, "Los talibanes primero se llevaron nuestra música, después nuestros Budas, después nuestra historia” (Yousafzai, 2013, p.139).

Todos los hechos anteriores constituyeron la historia vivida de Malala, fue el contexto de una joven habitante en un valle de infortunios. Luego de su reconocida labor, tanto nacional como internacionalmente, fue baleada y herida de muerte el 9 de octubre de 2012 dentro del automotor que la transportaba del centro educativo hacia su casa de habitación. En condición de gravedad fue trasladada en ambulancia al Hospital Central de Swat y de allí en helicóptero, a Peshawar para ser ingresada a la unidad de cuidados intensivos del Lady Reading Hospital. Finalmente fue trasladada a un centro hospitalario en Birminghan, Inglaterra. Aquí llegó a ser reconocida "como la niña a la que han disparado en la cabeza"

Malala despertó a miles de kilómetros de su natal Mingora y después de una difícil etapa de recuperación, se da cuenta que en Occidente las mujeres pueden vestir como deseen, pueden socializar con los hombres, pueden trabajar fuera de los hogares y pueden ocupar altos cargos en la política. Mientras tanto Malala piensa muy en su interior:

Algunas personas eligen caminos buenos y otros caminos malos. La bala de una persona me alcanzó. Me hinchó el cerebro, me privó del oído y cortó el nervio del lado izquierdo de mi cara en un segundo... En mi corazón sólo había deseado ayudar a la gente. No me interesaban los premios ni el dinero. Siempre rogaba a Dios: "Quiero ayudar a las personas, ayúdame a hacerlo" (Yousafzai, 2013, p. 326).

\section{Reflexiones finales}

Como se anotó en la introducción, el ejercicio académico de entender el pasado para comprender el presente se convierte en una operación útil como labor intelectual esmerada en encontrar respuestas acerca del acontecer más inmediato. En el caso específico de Malala, habitante de una región "pivote de la historia". A continuación se pasa enumerar algunas reflexiones de interés para ubicar la figura de Malala en un contexto más amplio dentro de las coordenadas espacio-temporales.

1. Pakistán forma parte de un entramado complejo dada su condición particular al tener como vecinos al este a la India contra quien ha librado un conflicto sin final en las guerras por la disputa por el territorio de Cachemira. En tanto que al noroeste comparte la frontera con Afganistán, un país con una historia propia, enraizada en el mundo bipolar y enmarcado en los últimos treinta años por las consecuencias derivadas de la invasión soviética de 1979; que fue, en definitiva, la primera y la última 
intervención directa en Asia durante la época de la Guerra Fría. Esta coyuntura histórica dio inicio con el arribo de las tropas de la URSS ocurrida durante la tercera y última fase del conflicto; en su conjunto, este período, que se prolongó por toda una generación, heredero de la segunda posguerra involucró a los países pobres de ahí que

La gran mayoría de los 20 millones de personas que murieron en las guerras que asolaron el globo entre 1945 y 1990 fueron víctimas de conflictos armados ocurridos en el Tercer Mundo, la mayoría de ellos relacionados al menos indirectamente con la Guerra Fría (McMahon, 2009, p. 183).

Años más tarde, como retoño de la Guerra Fría, una vez retirado el Ejército Rojo de Afganistán, surgió la guerra civil, causante de caos, miseria y negligencia internacional. Fue este el rescoldo dejado por este enfrentamiento entre el Este y el Oeste, según Hobsbawm (1996), el mundo quedó en un estado de confusión y parcialmente en ruinas.

2. Durante la posguerra fría, quizá el hecho más significativo ha sido el surgimiento del grupo talibán originario de los campos de refugiados afganos en Pakistán; sus dirigentes procedían de poblaciones pahstunes menos cultas y más pobres de Afganistán. Los talibán son cercanos al wahhabismo antishií, integrados principalmente por jóvenes estudiantes de las escuelas religiosas; junto con los refugiados, además de los antiguos adversarios de la invasión del Ejército Rojo a Afganistán; todos estos financiados y pertrechados por los Estados Unidos y Arabia Saudí, principalmente. Sin embargo, la confianza relativa de Occidente por los talibán acabó estrepitosamente con el ataque terrorista de Nueva York. Desde octubre de 2001 aún hoy permanecen tropas estadounidenses en el país que por tradición ha sido indómito al control permanente de los extranjeros; de ahí que tradicionalmente se refiera a Afganistán como "la tumba de los imperios".

En suma, el contexto más inmediato de Malala lo constituye una historia vivida en Pakistán en un entorno fundamentalista cuyos principios han sido divulgados sin tregua por los maulana, como Fazlullah a través de los medios de comunicación, quienes además de emitir mensajes por la radio, también tienen la costumbre de exhibir públicamente las flagelaciones perpetradas a quienes incumplen la ley.

3. Los maulana conforman así a los estudiosos del Islam y promueven, sin ambages, la aplicación de la sharia, la ley islámica. Junto con los talibán han emprendido una ardua lucha en contra de cualquier indicio de lo que a sus ojos pueda ser sinónimo de occidentalización como la práctica de la danza, el fútbol, hasta el vuelo de cometas; incluido, desde luego, el derecho de las mujeres a aprender a leer y a escribir. Ambos, maulana y talibán, han transformado todos los ámbitos de la vida del país de Malala; puesto que han dejado una impronta de inseguridad generalizada en regiones fronterizas como Swat, donde habitaba la joven pashtun hoy reconocida mundialmente como conferencista en grandes foros donde se destaca como portavoz del cambio de las sociedades a partir de la extensión de educación.

4. Finalmente, como cierre es necesario enfatizar con este ensayo la necesidad imperiosa de comprender estas realidades históricas ubicadas allende de las fronteras de los países centroamericanos; para ello se reproduce textualmente un fragmento que forma parte de una lección inaugural pronunciada por la profesora Hilda Chen Apuy en 1992, la pionera en el desarrollo de los estudios de Oriente en la Universidad de Costa Rica: 
"Los jóvenes deben aprender a respetar los valores de otros, para que no repitamos los comportamientos del racismo, prejuicios e intolerancia que hoy sufren otros pueblos. Sobre la base de un conocimiento de las diversas culturas, nuestros jóvenes podrán encontrar sus propias raíces culturales, su identidad, para sobrevivir en medio de las poderosas corrientes que agitan al mundo presente" (Chen-Apuy, 1992 p. 18).

\section{Referencias}

Armstrong, K. (2013). El Islam. Barcelona: Debate.

Baltar, Enrique. (2014). La agenda inconclusa de los refugiados afganos: El largo camino hacia la repatriación voluntaria. En Foro internacional, 4. 905-953. Recuperado de: http://bibliocodex.colmex.mx/exlibris/aleph/a21_1/apache_media/MQTXIDILCLJFIKEB4LGXDD1Q96VT N3.pdf

Baltar, E. (2012). Islam, nacionalismo y Estado en Pakistán. Estudios de Asia y África, 3, 621-676. Recuperado de: $\underline{\text { http://biblio- }}$ codex.colmex.mx/exlibris/aleph/a21_1/apache_media/B42UVS5C6URBRQ9P2NRN1NDXXFA $\underline{48 X . p d f}$

Bearden, M. (2002). La tumba de los imperios. Las traicioneras cumbres de Afganistán. En J. Hoge, y G. Rose (Comps.), ¿Por qué sucedió? El terrorismo y la nueva guerra (pp. 101-114). Barcelona: Paidós.

Bhutto, B. (2008). Reconciliación. El Islam, la democracia y el mundo occidental. Bogotá: Grupo Editorial Norma.

Braudel, F. (1989). La larga duración. En F. Braudel (Ed.), La historia y las ciencias sociales (pp. 60106). Madrid: Alianza.

Burbank, J. y Cooper, F. (2012). Imperios. Una nueva visión de la Historia universal. Barcelona: Crítica.

Chen-Apuy, H. (1992). Unidad y diversidad en un mundo cambiante. Reflexiones, 3. 13-18.

Cooley, J. R. (2002). Guerras profanas. Afganistán, Estados Unidos y el terrorismo internacional. Madrid: Siglo Veintiuno Editores.

Edwards, M. (2002). Asia Central. Detrás del velo. National Geographic, 2, 108-125.

Heller, A. (1999). Una filosofía de la historia en fragmentos. Barcelona: Gedisa.

Hobsbawm, E. (1996). Historia del siglo XX. Barcelona: Crítica.

Hourani, A. (2008). La historia de los árabes. Montevideo: Zeta Bolsillo.

Jaffrelot, C. (2002). Le Pakistan au coeur de tensions ethniques et de conflicts régionaux. En C. Jaffrelot (Dir.), Le Pakistan, Carrefour de tensions regionales (9-30). París: Editions Complexe. 
Judt, T. (2012). Postguerra: una historia de Europa desde 1945. Madrid: Taurus.

Kepel, G. (2002). La yihad. Expansión y declive del islamismo. Barcelona: Peninsula.

Kepel, G. (2005). La revancha de Dios. Madrid: Alianza Editorial.

Kienzler, K. (2011). El fundamentalismo religioso. Cristianismo, judaísmo, islamismo. Madrid: Alianza Editorial.

Mackinder, H. (2010). El pivote geográfico de la historia. Geopolítica (s) Revista de estudios sobre $\begin{array}{llllll}\text { espacios } & y & \text { poder, } & \text { 301-319. } & \text { Recuperado }\end{array}$ https://revistas.ucm.es/index.php/GEOP/article/viewFile/36331/35205

Maier, F. G. (1989). Las transformaciones del mundo mediterráneo, Siglos III-VIII. México: Siglo Veintiuno Editores.

Marín, R. (2005). El fundamentalismo islámico en el Medio Oriente Contemporáneo. San José: Editorial de la Universidad de Costa Rica.

Marín, R. (2002). Religión y globalización. La defensa de los valores culturales propios: El caso del fundamentalismo islámico. Revista Estudios, 16, 47-63.

McMahon, R. (2009). La Guerra Fría. Una breve introducción. Madrid: Alianza Editorial.

Menon, R. (2002). Una región agitada Los frágiles Estados de Asia Central y meridional. En J. Hoge y R. Gideon (Comps.), ¿Por qué sucedió? El terrorismo y la nueva guerra (115-126). Barcelona: Paidós

Newman, C. (2002). Una vida revelada. National Geographic, 4, 2-9.

Núñez, X. (2015). Las utopías pendientes. Una breve historia del mundo desde 1945. Barcelona: Crítica.

Pagden, A. (2011). Mundos en guerra, 2500 años de conflicto entre Oriente y Occidente. Barcelona: RBA.

Rashid, A. (2001). Los talibán: El Islam, el petróleo y el "Gran Juego” en Asia Central. Barcelona: Península.

Rogan, E. (2010). Los árabes: Del imperio Otomano a la actualidad. Barcelona: Crítica.

Ruthven, M. (2008). Epílogo. En A. Hourani, La historia de los árabes (pp. 549-563). Montevideo: Zeta Bolsillo.

Sánchez, E., Mañé, A., De la Cámara, C. y Huici, L. (2013). La transición geográfica de Asia Central en el nuevo contexto geográfico. En ICIP Working Papers, 7, 1-65. Recuperado de https://dialnet.unirioja.es/descarga/articulo/5523760.pdf

Sathar, Z. (2001). Fertility in Pakistan: past, presente and future. En Workshop on prospects for fertility decline in high fertility countries. Population Division. Department of Economic and Social 
El mundo de Malala: Una historia...

Affairs, New York: United Nations Secretariat. Recuperado de: www.un.org/esa/population/publications/.../sathar.pdf

Segura, A. (2001). Más allá del Islam. Política y conflictos actuales en el mundo musulmán. Madrid: Alianza Editorial.

Segura, A. (2013). Estados Unidos, el Islam y el nuevo orden mundial. Madrid: Alianza Editorial.

The Russian General Staff authors. (2002). The Soviet Afghan war. How a superpower fought and lost. Kansas: University Press of Kansas.

White, M. (2015). El libro negro de la humanidad: crónica de las grandes atrocidades de la historia. Barcelona: Crítica.

Yousafzai, M. (2013). Yo soy Malala. Madrid: Alianza Editorial.

Yousafzai, M. (2014a). Discurso de Malala Yousafzai en la recepción del Premio Nobel de la Paz 2014. Recuperado de: http://pediatriasocial.es/HtmlRes/Files/DiscursoMalala.pdf

Yousafzai, M. (2014b). Malala mi historia. Madrid: Alianza Editorial.

Zéraoui, Z. (2009). Medio Oriente: La nueva geopolítica del poder. Irán y el nuevo equilibrio regional. Cuadernos de la Cátedra "Ibn Khaldun" de Estudios de Medio Oriente y África del Norte. San José: Editorial de la Universidad de Costa Rica. 


\section{¿Cómo citar este artículo?}

Agüero García, J. (2017). El mundo de Malala: Una historia vivida en un contexto coyuntural heredero de la Guerra Fría. Revista humanidades, 7(2). doi: http://dx.doi.org/10.15517/h.v7i2.29594 